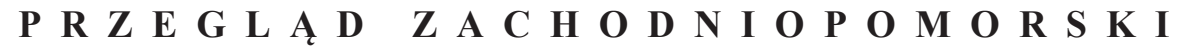 ROCZNIK XXXV (LXIV) ROK 2020 ZESZYT 1
}

$\begin{array}{lllllllll}\mathbf{A} & \mathbf{R} & \mathbf{T} & \mathbf{Y} & \mathbf{K} & \mathbf{U} & \mathbf{L} & \mathbf{Y}\end{array}$

\author{
ŁuKASZ KoREMBA \\ ORCID: 0000-0003-3434-3098 \\ Uniwersytet Szczeciński \\ e-mail: lukasz.koremba@phd.usz.edu.pl
}

\begin{abstract}
APPARATUS SIGILLORUM - NIEZNANE ŹRÓDŁO
do sfragistyki miejskiej Pomorza Zachodniego. Autorstwo, CZAS I OKOLICZNOŚCI POWSTANIA
\end{abstract}

Słowa kluczowe: sfragistyka, pieczęcie, Pomorze Zachodnie, Biblioteka Ostenów, Apparatus Sigillorum, odrysy pieczęci

Keywords: sphragistics, seals, Western Pomerania, the Ostens Library, Apparatus Sigillorum, copies of seals

Autor podejmujący badania nad rozwojem pieczęci miejskich musi brać pod uwagę problemy związane z bazą źródłową. Materiał źródłowy w postaci tłoków czy reprodukcji pieczęci jest zazwyczaj silnie rozproszony. Wiele sigillów używanych przez miasta nie zachowało się do naszych czasów bądź nie zostało jeszcze odnalezionych w zasobach archiwów. Dlatego tak istotne dla sfragistyki miejskiej są dawne dzieła zawierające rysunki lub opisy pieczęci. Oczywiście należy podchodzić do nich z dużą dozą krytycyzmu, jednak jeśli tylko uda się potwierdzić ich wiarygodność, mogą stanowić uzupełnienie do naszej wiedzy z zakresu sfragistyki.

W niniejszym opracowaniu podjęto rozważania nad jednym $\mathrm{z}$ tego typu dzieł, a mianowicie Apparatus Sigillorum Pomeraniae et Rugiae Civitatum ${ }^{l}$,

\footnotetext{
${ }^{1}$ Landesarchiv Greifswald (dalej: LAG), Rep. 41 Plathe, Nr. I 41.
} 
które do tej pory nie było na ogół brane pod uwagę przez badaczy². Omawiane dzieło to katalog pieczęci miast, cechów, parafii i innych instytucji pomorskich z okresu średniowiecza i nowożytności, wobec czego stanowić może ciekawe źródło do badań z zakresu zarówno sfragistyki, jak i heraldyki pomorskiej. Celem rozważań jest próba odpowiedzi na pytanie o autorstwo dzieła oraz czas i okoliczności powstania. Niestety w Apparatus Sigillorum trudno znaleźć na ten temat jakieś wskazówki. Nie ma także innych źródeł mówiących bezpośrednio o tym dziele, wobec powyższego, wiele z poczynionych ustaleń musi pozostać w sferze hipotez. W artykule wskazano na pewne kierunki badań, które mogą pomóc w rozwikłaniu zagadki powstania Apparatus Sigillorum.

W pracy korzystano z literatury traktującej o historii kolekcji Matthäusa Heinricha Liebeherra oraz Fryderyka Wilhelma von der Ostena, tj. środowisk, w których omawiane dzieło funkcjonowało³. Przydatne okazały się także

2 W dotychczasowej literaturze przedmiotu, za wyjątkiem Dariusza Bieńka („Od pieczęci do herbu", Gazeta Płotowska, 3, 2016: 3), nie powoływano się na informacje źródłowe zawarte w omawianym dziele, jak i nie podjęto próby krytycznej analizy tegoż, zob. m.in.: Bogdan Bobowski, „Motywy gospodarcze na pieczęciach średniowiecznych i wczesnonowożytnych Goleniowa", w: Najnowsze badania nad numizmatyka i sfragistyka Pomorza Zachodniego: Materiaty z konferencji naukowej 50 lat Działu Numizmatycznego Muzeum Narodowego w Szczecinie 19-20 września 2002 roku, red. Genowefa Horoszko (Szczecin: Muzeum Narodowe, 2004), 185-189; Kazimierz Bobowski, „Symbolika religijna i kościelna w ikonografii pieczęci miast Pomorza Zachodniego", tamże, 179-184; tenże, „Symbolika pieczęci i herbu miasta Dymina na tle motywów obrazowych pieczęci miejskich Pomorza Zachodniego", Śląski Kwartalnik Historyczny Sobótka, 43 (1988), 2: 245-254; tenże, Dawne pieczęcie na Pomorzu Zachodnim: zabytki prawa i kultury z epoki Gryfitów (Szczecin: Glob, 1989); Marian Gumowski, „Koszalin - jego herb i pieczęcie”, w: Z dziejów Koszalina, red. Henryk Janocha (Poznań: Wydawnictwo Poznańskie, 1960), 95-106; tenże, „Pieczęcie i herb Słupska”, Zapiski Koszalińskie 4 (1959): 3-14; tenże, „Pieczęcie i herby niektórych miast pomorskich”, Przegląd Zachodniopomorski 15 (1971), 3: 113-132; Paweł Gut, „Typariusze pieczęci miejskich i sądowych z herbami miejskimi w zasobie Archiwum Państwowego w Szczecinie", Stargardia 4 (2004), 323-335; Otto Hupp, Die Wappen und Siegel der Deutschen Städte, Flecken und Dorfen (München, 1898).

3 Sabinne Beckmann, „Drucker, Sammler, Gelehrte. Eine Literatur-und Kulturgeschichte Westpommerns im Spiegel frühneuzeitlicher Gelegenheitkunst”, w: Handbuch des Personalen Gelegenheitsschrifttums in Europäischen Bibliotheken und Archiven, Bd. 27, hrsg. v. Sabinne Beckmann, Stefan Anders, (Hildesheim-Zürich New York: Olms-Weidmann, 2013), 17-195; Ferdinand von Bismarck-Osten, „Die Sammlungen zu Schloss Plathe und ihr Begründer Friedrich Wilhelm von der Osten (1721-1786)", Baltischen Studien 62 (1976): 63-72; Wilhelm Böhmer, „Uebersicht der allgemeine Chroniken und Geschichten Pommerns seit Kantzow”, Baltische Studien 3 (1835), 1: 66-171; Edward Rymar, „Biblioteka Ostenów w Płotach (1)”, Bibliotekarz Zachodniopomorski 45 (2004), 3-4: 36-44; Vanessa de Senarclens, „Części rozproszonych księgozbiorów XVIII-wiecznych. Biblioteka zamku Plathe i jej użytkownicy”, w: Unbekannte Schätze. Germanica des 16. Jahrhunderts in der Universitätsbibliothek Łódź/ Nieznane skarby. Germanika XVI-wieczne w zbiorach Biblioteki Uniwersytetu Lódzkiego, red. Cora Dietl, Małgorzata Kubisiak (Łódź: Wydawnictwo Uniwersytetu Łódzkiego, 2018), 117-146; Aleksandra Skiba, 
opracowania na temat osiemnastowiecznego kręgu pomorskich uczonych ${ }^{4}$, pewne bowiem ślady znajdujące się w omawianym tekście wskazują na związki tegoż z intelektualistami skupionymi wokół uniwersytetu greifswaldzkiego oraz działającego tam stowarzyszenia Collectores Historiae et Juris Patrii.

\section{Cechy formalne dzieła}

\section{Apparatus Sigillorum Pomeraniae et Rugiae Civitatum}

Apparatus Sigillorum Pomeraniae et Rugiae Civitatum to poszyt o wymiarach 315 x $200 \mathrm{~mm}$, posiadający sześćdziesiąt niepaginowanych, jednostronnie zapisanych papierowych kart. Stan techniczny stronnic można określić jako dobry, ze śladową ilością przebarwień. Na niektórych stronach występują delikatne zakreślenia mogące być pozostałością po dawnych czytelnikach. W o wiele gorszym stanie znajduje się papierowa okładka - jest mocno przetarta i poplamiona. Wszelkie zapiski i szkice wykonano odręcznie. Narzędziem pisarskim mógł być w przypadku rysunków pędzel, natomiast do zapisków używano pióra.

$\mathrm{Na}$ okładce poszytu, będącej jednocześnie stroną tytułową, widnieje zapisany pismem humanistycznym tytuł:

APPARATUS SIGILLORUM

POMERANIAE ET RUGIAE CIVITATUM

Poniżej zaś znajduje się mało wyraźna notatka:

Alle diese Sigilla in hoc Apparatu

Sind meistenthails in naa zu

Stettin auch in Locis vorhanden

\footnotetext{
„Kolekcja Matthäusa Heinricha Liebeherra w bibliotece Gimnazjum Akademickiego w Szczecinie", w: Od Pedagogium Książęcego do Gimnazjum Mariackiego. Z dziejów szkolnictwa pótwyższego w Szczecinie do początków XIX w., red. Agnieszka Borysowska (Szczecin: Książnica Pomorska im. Stanisława Staszica, 2018), 159-171.

${ }^{4}$ Detlef Döring, „Gelehrte Gesellschaften in Pommern im Zeitalter der Aufklärung”, w: Die Universität Greifswald in der Bildungslandschaft des Ostseeraums, red. Dirk Alvermann, Nils Jörn, Jens E. Olesen (Berlin: LIT Verlag, 2007), 123-153; Theodor Pyl, hrsg., Dr. j. u. Augustin Balthasars [...] Leben und Schriften nach dessen Selbstbiographie und anderen urkundlichen Quellen als Ergänzung zu O. Focks Rügisch-Pommerscher Geschichte (Greifswald, 1875); tenże, „Schwarz, Albert Georg”, w: Allgemeine Deutsche Biographie 33 (1891), 223-226; Maciej Szukała, Powstanie i działalność Towarzystwa Historii i Starożytności Pomorza w Szczecinie w latach 1824-1918 (Szczecin: Wydawnictwo Archiwum Państwowego „Dokument” w Szczecinie, 2000)
} 
Nad skrótem „naa” umieszczono poziomą kreskę - znak kontrakcji. Kolejny istotny zapisek umieszczono z prawej strony środkowej części okładki - to podpis właściciela poszytu.

FW Osten

Plates 1773

Ex donatio De(?)de Liebeherr

Jedynym zdobieniem okładki są „esy-floresy”. Poza zapiskami, na obwolucie znajdują się oznaczenia dawnego miejsca przechowywania, takie jak np.: zapisana ołówkiem przy górnej krawędzi sygnatura $I$ A $5 I$, atramentowy odcisk podłużnej pieczęci biblioteki w zamku w Płotach, a także przyklejony exlibris tejże biblioteki. Nad naklejką exlibrisu zapisano niebieskim atramentem liczbę 41 .

W poszycie umieszczono odrysy pieczęci 66 miast pomorskich, a więc wszystkich, które wchodziły w skład Księstwa Pomorskiego pod rządami Gryfitów: Altentreptow, Anklam, Banie, Barth, Barwice, Bergen auf Rügen, Białogard, Bobolice, Bytów, Chociwel, Damgarten, Darłowo, Dąbie, Demmin, Dobra, Dobrzany, Franzburg, Gartz (Oder), Garz/Rügen, Goleniów, Greifswald, Grimmen, Gryfice, Gryfino, Gützkow, Jarmen, Kamień Pomorski, Karlino, Kołobrzeg, Koszalin, Lassan, Lębork, Loitz, Łeba, Łobez, Maszewo, Miastko, Nowe Warpno, Nowogard, Okonek, Pasewalk, Penkun, Płoty, Polanów, Police, Połczyn, Pyrzyce, Resko, Richtenberg, Sianów, Sławno, Stargard, Słupsk, Stralsund, Strzmiele, Suchań, Szczecin, Szczecinek, Tribsees, Trzebiatów, Ückermünde, Usedom, Węgorzyno, Wierzbno, Wolgast, Wolin 5 .

Układ treści na kolejnych stronach dzieła jest w większości przypadków podobny: u góry stron umieszczono napis Sigillum civitatis (tu pada łacińska nazwa danego miasta), poniżej zaś znajdują się odrysy pieczęci tegoż ośrodka. Jednemu miastu odpowiada jedna strona dzieła, za wyjątkiem Szczecina i Greifswaldu, których pieczęcie rozmieszczono na dwóch stronicach. Warto dodać, że w przypadku Szczecina na drugiej stronie umieszczono pieczecie cechowe, natomiast druga strona poświęcona Greifswaldowi zawiera pieczęcie tamtejszego uniwersytetu.

Nieco inaczej zaprezentowano pieczęcie piętnastu miast, w przypadku: Bobolic, Bytowa, Bergen auf Rügen, Barwic, Karlina, Garz/Rügen, Dobrzan, Lęborka, Łeby, Polanowa, Miastka, Strzmiela, Ückermunde, Węgorzyna, Sianowa, wizerunki pieczęci tych miejscowości umieszczono w wolnych przestrzeniach

${ }^{5}$ W niniejszym artykule posłużono się współczesnymi nazwami miejscowości zarówno polskimi, jak i niemieckimi. 
stronic. Zamiast formy Sigillum civitatis zastosowano tu nazwy niemieckie ośrodków. Również charakter pisma wskazuje na innego pisarza. Najprawdopodobniej pieczęcie tych miast dorysował kolejny użytkownik dzieła. Warto zaznaczyć, że wyżej opisane miasta w większości przypadków znajdują się we wschodniej części regionu, co może wskazywać na miejsce pochodzenia tej osoby.

Rozkład ilościowy odrysów przedstawiono w tabeli 1. Najwięcej szkiców pieczęci odnotowano w przypadku Szczecina, natomiast w przypadku pozostałych miejscowości wskazywano 2-3. Można na tej podstawie sformułować wniosek, że największe pomorskie miasta posiadały w przeszłości wiele pieczęci, stąd też autor skompletował większą bazę źródłową dla tych ośrodków.

Tabela 1. Liczba odrysów pieczęci wg miast przedstawionych w Apparatus Sigillorum

\begin{tabular}{|l|c|}
\hline \multicolumn{1}{|c|}{ Współczesna nazwa miasta } & $\begin{array}{c}\text { Liczba odrysów } \\
\text { pieczętnych }\end{array}$ \\
\hline Szczecin & 32 \\
\hline Stargard & 15 \\
\hline Demmin & 13 \\
\hline Greifswald & 12 \\
\hline Wolin & 11 \\
\hline Anklam, Gryfino, Barth & 9 \\
\hline Wolgast, Kamień Pomorski, Kołobrzeg & 8 \\
\hline Pyrzyce & 7 \\
\hline Sławno, Stralsund, Gartz (Oder), Banie, Gryfice, Darłowo & 6 \\
\hline Altentreptow, Goleniów, Grimmen, Białogard, Dąbie, Nowogard & 5 \\
\hline Słupsk, Gützkow, Pasewalk, Szczecinek, Koszalin, Usedom & 4 \\
\hline $\begin{array}{l}\text { Dobra, Nowe Warpno, Trzebiatów, Chociwel, Franzburg, Resko, } \\
\text { Damgarten, Uckermünde, Penkun, Węgorzyno, Łobez, Dobrzany, } \\
\text { Maszewo, Loitz }\end{array}$ & 3 \\
\hline $\begin{array}{l}\text { Lassan, Garz/Rügen, Połczyn, Bobolice, Tribsees, Jarmen, Płoty, } \\
\text { Richtenberg, Suchań, Sianów, Bergen in Rugen, Bütow, Okonek, Karlino, } \\
\text { Lębork, Miastko, Police, Mieszkowice, Strzmiele, Łeba }\end{array}$ & 2 \\
\hline Wierzbno, Polanów & 1 \\
\hline
\end{tabular}

Źródło: obliczenia własne na podstawie Apparatus Sigillorum (LAG, Rep. 41 Plathe, Nr. I 41).

Odrysy pieczęci różnią się wielkością i jakością wykonania, obok starannie odwzorowujących treść pola pieczętnego, wzbogaconych o światłocienie, jak np. w przypadku pieczęci Anklam i Kołobrzegu, znajdują się odrysy przedstawione w sposób niestaranny i schematyczny, czego ewidentnym przykładem są rysunki 
pieczęci Miastka (poniżej zestawienie odmiennych pod względem estetyki wykonania odrysów pieczęci). Nota bene odwzorowaną tutaj pieczęć Miastka (Rummelsburg) zaliczyć można do opisanej powyżej kategorii pieczęci prawdopodobnie dodanych przez kolejnego użytkownika. Niski poziom wykonania jest charakterystyczny dla wszystkich piętnastu pieczęci, których układ odbiega od przedstawionego schematu (co potwierdzałoby tezę, że są one autorstwa kolejnego użytkownika).

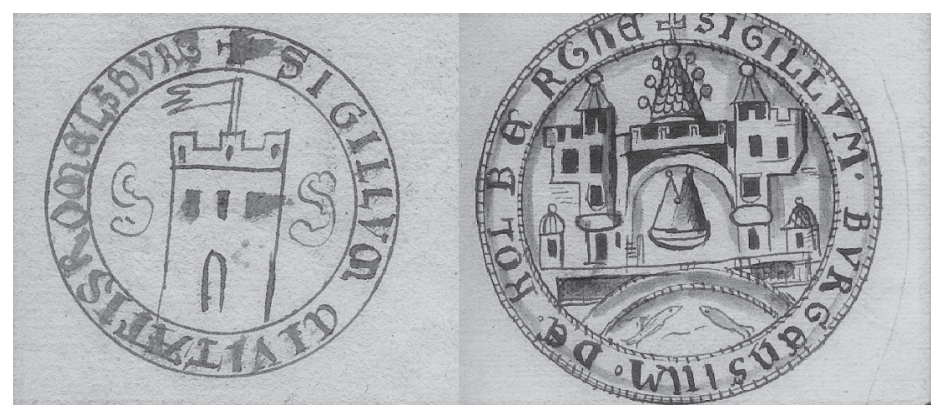

Rycina 1.

Zestawienie rysunku pieczęci Kołobrzegu i Miastka (LAG, Rep. 41 Plathe, Nr. I 41)

Ważnym urozmaiceniem treści poszytu są nieregularnie pojawiające się odręczne dopiski. Większość z nich ma postać liczby, którą można interpretować jako rok, czasami występującej ze słowem gebraucht. Taka forma zapisu datacji nie wyjaśnia do końca, czy podany rok to data wprowadzenia do użytku pieczęci, czy może jest to data dokumentu, do którego przywieszona była pieczęć stanowiąca wzór danego odrysu. Czasem dopisek określa dysponenta pieczęci, jak np. Kirche siegel. Bardziej rozbudowane dopiski wskazują na miejsce przechowywania tłoka, czy nawet - jak w przypadku notatki przy pieczęci Chociwla wyjaśniają symbolikę wizerunku napieczętnego ${ }^{6}$. Zapiski wykonano w języku niemieckim, charakterystycznym dla osiemnastego wieku i rejonu Pomorza pruskiego, pismem neogotyckim. Przy okazji analizy notatek znów pojawia się kwestia ustalenia momentu, w którym powstały i ich bezpośredniego autorstwa. Nieregularne występowanie zapisków i nieestetyczne wkomponowanie ich w układ pieczęci na stronach pozwala przypuszczać, że wszystkie notatki powstały jakiś

${ }^{6}$ Treść notatki: „Dieses Wapen der Stadt Freyen Wald führet theils ein Wedelsches, theils ein bischöfliches caminisches Wapen, weil so wohl der Bischoff, als auch die v. Wedele die Iurisdiction über diesen Orth commune gehabt haben". 
czas po powstaniu rękopisu dzieła, prawdopodobnie były sporządzane w trakcie jego użytkowania. Charakter pisma wskazuje ewidentnie na jednego autora wszystkich dopisków.

\section{Problem autorstwa dziela Apparatus Sigillorum}

Na poszycie Apparatus Sigillorum nie umieszczono bezpośredniej informacji o twórcy dzieła ani o dacie jego powstania. Jedynie zamieszczona na okładce krótka notka informuje, że poszyt został podarowany przez Liebherra Fryderykowi Wilhelmowi von der Ostenowi - podpis FW Osten - w 1773 roku? Informacja o tym, że dzieło pochodzi z biblioteki Liebeherra znajduje się także w katalogu kartkowym Biblioteki Ostenów ${ }^{8}$. Niestety, nie zapisano wprost kto był twórcą dzieła ani kiedy ono powstało - wątpliwe wydaje się, by powstało w roku donacji. Wobec tego należy przyjrzeć się środowiskom, w których funkcjonowało, a więc osiemnastowiecznym kolekcjom dokumentów, i ustalić w ramach której z nich mogło powstać. Nie można wykluczyć, że posiadacz danej kolekcji był zarazem autorem omawianego dzieła. W przypadku osiemnastowiecznego kolekcjonerstwa tworzenie dzieł o charakterze syntetycznym, na podstawie posiadanych zbiorów, nie było niczym nowym, najlepszym przykładem takiego zjawiska było sporządzanie przez Fryderyka Wilhelma v. der Ostena tablic genealogicznych szlachty pomorskiej, na podstawie informacji ze swojej kolekcji9.

Niewątpliwie pierwszym miejscem funkcjonowania dzieła, które należy przeanalizować jest Biblioteka Ostenów, w pozostałościach której poszyt zachował się do naszych czasów. Oczywiście wspomniany zapis na okładce: ex donatio Liebeherr od razu wyklucza kolekcję Ostenów jako środowisko, w którym spisywanie dzieła zostało zapoczątkowane, jednak nie możemy także stwierdzić, że Ostenowie nie dokonywali jego uzupełnień. Następnie warto zwrócić uwagę na kolekcję, z której to dzieło trafiło do rąk Ostenów, a więc zbiory owego Liebeherra. Można przypuszczać, że donacja pochodziła z istniejącej w tym czasie kolekcji Matthäusa Heinricha von Liebeherra, szczecińskiego burmistrza, którego związki z Fryderykiem Wilhelmem von der Ostenem zostaną przedstawione

\footnotetext{
${ }^{7}$ LAG, Rep. 41 Plathe, Nr. I 41.

8 Zdigitalizowany katalog jest dostępny w internecie: Zettelkatalog der Bibliothek, Bismarck-osten.com, dostęp: 28.01.2020, http://www.bismarck-osten.com/zettelkatalog.

9 Johann Bernouilli, Reisen durch Brandemburg, Pommern, Preussen, Curland, Russland und Pohlen in den Jahren 1777 und 1778, Bd. 2 (Leipzig, 1779-1780), 179; Bismarck-Osten, „Die Sammlungen" 67.
} 
poniżej. W celu ustalenia okoliczności powstania dzieła oraz źródeł, z których autor/autorzy czerpali informacje o pieczęciach, warto przyjrzeć się także działalności stowarzyszenia naukowego Collectores Historiae et Juris Patrii funkcjonującego w tym okresie na Pomorzu, którego członkiem był wspomniany Matthäus Heinrich von Liebeherr ${ }^{10}$.

Początek i rozkwit Biblioteki Ostenów wiąże się z postacią urodzonego w 1721 roku w Stargardzie Fryderyka Wilhelma von der Ostena. Tenże pomorski szlachcic i syn pruskiego urzędnika otrzymał wszechstronne wykształcenie studiował m.in. na uniwersytetach we Frankfurcie nad Odrą i w Królewcu. Większość swojego życia spędził administrując rodzinnym majątkiem w Płotach oraz pełniąc urząd landrata tzw. Powiatu Ostenów. W 1752 roku ożenił się z Charlottą Henriettą von Liebeherr, córką wspomnianego już szczecińskiego burmistrza Matthäusa Heinricha von Liebeherra. Historycy uważają, że to właśnie ten związek stał początkiem kolekcjonerskich pasji Fryderyka Wilhelma, gdyż jego teść posiadał znaczną kolekcję starodruków i monet ${ }^{11}$. Poza inspiracją, Liebeherr przekazał również zięciowi znaczą część swoich zbiorów - zwłaszcza monety ${ }^{12}$. Kolekcja Fryderyka Wilhelma von der Ostena gromadzona na zamku w Płotach obejmowała rękopisy pergaminowe, książki, miedzioryty, mapy, tablice genealogiczne, obrazy przedstawiające książąt pomorskich, a także pomorskie kroniki. Wszystko to związane było bezpośrednio z historią Pomorza, której Fryderyk Wilhelm był entuzjastą. Wiele pomorskich dzieł posiadanych przez Liebeherra zostało skopiowanych przez Fryderyka Wilhelma i włączonych do jego kolekcji13.

Biblioteka Ostenów po śmierci Fryderyka Wilhelma (1786) pozostała nienaruszona w rękach rodu, zgodnie z ostatnią wolę jej twórcy. Dopiero w roku 1945, w obawie przed zbliżającymi się oddziałami radzieckimi, Karol hrabia Bismarck-Osten próbował wywieźć w głąb Niemiec załadowaną na wagony kolejowe bibliotekę. Tylko część kolekcji udało się ewakuować, co skutkowało rozproszeniem zbiorów, z których część - a w niej omawiane dzieło - trafiła do archiwum w Greifswaldzie ${ }^{14}$.

10 Lista członków stowarzyszenia: Greifswaldisches Wochen-Blatt von allerhand gelehrten und nützlichen Sachen (Greifswald, 1743), 15.

11 Bismarck-Osten, „Die Samlungen”, 64; Rymar, „Biblioteka (1)”, 38; Senarclens, „Części”, 144.

12 Bismarck-Osten, „Die Samlungen”, 65; Rymar, „Biblioteka (1)”, 38; Böhmer, „Uebersicht” 120.

13 Bismarck-Osten, „Die Samlungen”, 66; Rymar, „Biblioteka (1)”, 38.

14 Na temat rozproszenia zbiorów zob. Edward Rymar, „Biblioteka Ostenów - Bismarcków w Płotach część 2. Tajemnice rozproszenia”, Bibliotekarz Zachodniopomorski 46 (2005): 41-53; 
Przy okazji omawiania zasobów Biblioteki Ostenów warto zwrócić uwagę na jeszcze jeden fakt. W 1778 roku Fryderyka Wilhelma von der Osten odwiedził szwajcarski podróżnik Johann Bernouilli, który w swoim dzienniku podróży wymienił kategorie dzieł znajdujących się w zbiorach pomorskiego szlachcica $^{15}$. Niestety ani Apparatus Sigillorum, ani kolekcja pieczęci nie zostały tam wspomniane. Przeoczenie niewielkiego poszytu pośród setek dzieł nie powinno dziwić, jednak brak wzmianki na temat kolekcji pieczęci pozwala wysnuć przypuszczenie, że Apparattus Sigillorum nie mógł być katalogiem pieczęci przekazanych przez Liebherra Ostenowi. Oczywiście brak wydzielonej kolekcji nie musiał oznaczać kompletnego braku pieczęci w zbiorach Ostena, mogły się w niej znajdować dokumenty z przywieszonymi pieczęciami.

Jak już wspomniano, dzieje Biblioteki Ostenów wiążą się nierozerwalnie z kolekcją Matthäusa Heinricha von Liebeherra. Urodzony w roku 1693, w rodzinie mieszczańskiej, tytuł szlachecki uzyskał w roku 1727 i w tymże roku objął urząd burmistrza Szczecina, sprawując go do śmierci (1749). Zainteresowanie historią regionu oraz kwestiami prawniczymi zaowocowały gromadzeniem przezeń kolekcji ksiąg, kronik, map i dokumentów związanych z historią Pomorza, a także monet i medali ${ }^{16}$. Swoją aktywność naukową w dziedzinie historii prawa rozwijał, współpracując z ówczesną pomorską elitą doby oświecenia, przede wszystkim z Augustinem Balthasarem, w ramach stowarzyszenia Collectores Historiae et Juris Patrii ${ }^{17}$.

Większość zbiorów Liebeherra, zwłaszcza księgozbiór, została po jego śmierci przekazana w roku 1754 do biblioteki Gimnazjum Akademickiego w Szczeci$n^{1 e^{18}}$. Reszta zbiorów pozostała pod opieką jego dzieci w posiadłości w Woiftick (Oćwieka) do roku 1794, kiedy to posiadłość wraz ze zdeponowaną tamże kolekcją sprzedano. Grabieże dokonane przez żołnierzy napoleońskich doprowadziły do rozproszenia zbiorów ${ }^{19}$.

tenże, Biblioteka Ostenów - Bismarcków w Płotach część 3. Stare i nowe tropy rozproszenia zbiorów”, Bibliotekarz Zachodniopomorski 50 (2009), 3-4: 32-35.

15 Bernouilli, Reisen, 175-181.

16 Skiba, „Kolekcja” 161; Urszula Szajko, „Liebeherr Mathaus Heinrich von”, w: Encyklopedia Szczecina, t. 1, red. Tadeusz Białecki (Szczecin: Uniwersytet Szczeciński, 1999), 542.

17 Böhmer, „Uebersicht”, 114; Döring, „Gelehrte”, 149; Skiba, „Kolekcja”, 161.

${ }^{18}$ Więcej na temat tejże darowizny zob. Skiba, „Kolekcja”, 159-171.

19 Tamże, 162. 
Z powyższego wynika, że w roku 1773, kiedy Apparatus Sigillorum został podarowany Fryderykowi Wilhelmowi v. der Ostenowi, kolekcja znajdowała się pod opieką dzieci Liebeherra, a dokładniej dwóch jego synów - Carla Albrechta oraz Augustyna, którzy podzielili między siebie majątek w Oćwiece ${ }^{20}$. Niestety ze względu na niewyraźny inicjał występujący na okładce poszytu, nie jesteśmy w stanie stwierdzić, który z braci dokonał donacji. Być może, jak w przypadku darowizny na rzecz Gimnazjum Akademickiego, dokonano jej wspólnie. Otwartym musi również pozostać pytanie, czy wraz z poszytem nie przekazano innych materiałów. Można przypuszczać, że Apparatus Sigillorum powstał z inicjatywy samego Matthäusa Heinricha Liebeherra, gdyż nie ma informacji jakoby potomkowie Liebeherra kontynuowali jego kolekcjonerskie zainteresowania.

W przypadku uznania Matthäusa Heinricha Liebeherra za twórcę omawianego poszytu, należy jeszcze zastanowić się, skąd mogły płynąć inspiracje do stworzenia tego dzieła, jakie środowisko wspierało Liebeherra w pracy i przede wszystkim użyczało swoich zbiorów do opracowania. Wydaje się, że za takie środowisko można uznać naukowe stowarzyszenie Collectores Historiae et Juris Patrii.

Rzeczone stowarzyszenie zostało założone przez Augustina Balthasara profesora prawa na tamtejszym uniwersytecie, jego brata Jacoba Heinricha oraz Johanna Franza von Boltensterna. Celem stowarzyszenia było badanie pomorskiej historii w jej prawnym aspekcie ${ }^{21}$. Na jego czele stali senior i consenior - odpowiednio A. Balthasar i J.F. Boltenstern ${ }^{22}$. Rok po powstaniu organizacji ukazał się pierwszy numer periodyku „Greifswaldische Wochen-blatt”, w którym poza informacją o założeniu stowarzyszenia opublikowano raport z jego dotychczasowych prac, regulamin i listę członków ${ }^{23}$. Zebrania członkowskie odbywały się co miesiąc $\mathrm{w}$ domu jednego $\mathrm{z}$ seniorów, podczas nich dzielono się tematami do opracowania z zakresu historii prawnej Pomorza oraz odczytywano dotychczas

20 Ludwig Wilhelm Brüggemann, Ausführliche Beschreibung des gegenwärtigen Zustandes des Königl. Preussischen Herzogthums Vor-und Hinter-Pommern, 2 Th., Bd. 1 (Stettin 1784), 169.

${ }^{21}$ Böhmer, „Uebersicht”, 114; Döring, „Gelehrte”, 149; A. Häckermann, „Balthasar, Augustin von", w: Allgemeine Deutsche Biographie 2 (1875), 29-30; Pyl, Dr. j . u. Augustin Balthasars, 69; Szukała, Powstanie, 44.

22 Böhmer, „Uebersicht”, 114; Pyl, Dr.j. u. Augustin Balthasars, 69.

23 Greifswaldisches Wochen-Blatt, 7-8; 10-15. 
powstałe referaty ${ }^{24}$. Efektem pracy Collectores Historiae et Juris Patrii były dwie edycje dokumentów pomorskich z roku 1747 i $1756^{25}$.

$\mathrm{Na}$ związek omawianego stowarzyszenia z dziełem Apparatus Sigillorum wskazuje nie tylko członkostwo Liebeherra, ale także nazwiska pojawiające się w zapiskach dorsalnych na jego kartach, dlatego warto poddać je analizie. Przy odrysach pieczęci Barwic znajdujemy taki oto zapisek: „hat hr. Proffesor Schwartz de anno 1490". Zapewne chodzi o Alberta Georga Schwarza, historyka i profesora Uniwersytetu w Greifwsaldzie, członka Collectores Historiae et Juris Patrii ${ }^{26}$. Dalej, przy odrysach należących do Demminu zapisano: „Kirchen Siegel J. Barthol", prawdopodobnie wspomniany to należący do stowarzyszenia Johann Christian Bartholdi. Nazwisko Balthasar pojawia się przy odrysach: Garz Rügen treść zapisku: „Sind bei hr. Docktor Balthasar zu finden”, Dobrzan - „Siegel der Kirche zu Jacobshagen. 1500. Ist bey hr. Doctor Balthasar” i Suchania - „hat hr. Doctor Balthasar", bez zastrzeżeń można uznać, że jest to wspomniany Augustin Balthasar, senior stowarzyszenia. Odrysy sigillów Grimmen opatrzono notatką, w której wspomniano M.A.C. Brunsta, prepozyta z Grimmen i członka stowarzyszenia - ,ist gebraucht in einer Schuldverschreibung der Stadt Grimmen an die von Walkenitze zu Clenow 1616 am Tage Michaelis und ist in originali bei hr. Magister Brunst Praeposito daselbst vorhanden”. Wreszcie nazwisko Charisius padło przy odwzorowaniach pieczęci Nowogardu - „1680 hat hr. Doctor Balthasar und ist in Stralsund bey hr. Bürgermeister Charisio zu finden", prawdopodobnie jest to Christian Ehrenfried Charisius, zmarly w 1773 r. burmistrz Stralsundu ${ }^{27}$.

Z zestawienia wynika, że każda z osób wymienionych w Apparatus Sigillorum należała do stowarzyszenia Collectores Historiae et Juris Patrii. Ponadto M.H. Liebeherr tworząc poszyt korzystał z pieczęci znajdujących się w kolekcjach wymienionych osób. Interesujące jest to, że stowarzyszenie w swoim regulaminie miało zapisek o wzajemnym udostępnianiu swoich zbiorów przez członków organizacji:

${ }^{24}$ Döring, „Gelehrte”, 151; Greifswaldisches Wochen-Blatt, 12; Pyl, Dr. j. u. Augustin Balthasars, 69.

25 Döring, „Gelehrte”, 151-152.

${ }^{26}$ Informacje na temat członkostwa w stowarzyszeniu pochodzą głównie z listy umieszczonej w Greifswaldisches Wochen-Blatt, 15; jednak za Pyl, (Dr. j. u. Augustin Balthasars, 70-72) listę można rozszerzyć na inne osoby biorące udział w pracach stowarzyszenia.

${ }^{27}$ Häckermann, „Charisius, Johann Ehrenfried”, w: Allgemeine Deutsche Biographie (Leipzig, 1876), 103. 
VII. (...) Dazu ihm denn alle und jede Mitglieder, aus dem etwanigen Vorrath ihrer Sammlungen, auf geschehenes Ansuchen, Zuschub und Anleitung zu thun schuldig sein sollen. Es muß aber das solcher gestalt communicirte nach den Gebrauch dem Eingenthümer getreulich wieder abgeliefert werden $(. .)^{28}$.

Czy wobec powyższego Apparatus Sigillorum mógł powstać w ramach pracy stowarzyszenia? Jest to bardzo możliwe, w końcu opracowanie zestawiające pieczęci miejskie funkcjonujące na Pomorzu łączy w sobie zarówno aspekt prawno-ustrojowy, jak i historyczny. Jeśli uznamy powyższą hipotezę za słuszną, będziemy mogli nie tylko zrozumieć cel stworzenia omawianego dzieła, ale także określić w dużym przybliżeniu czas jego powstania. Otóż według powyższego poszyt powinien powstać między rokiem 1742 (początek pracy stowarzyszenia) a 1749 (śmierć M.H. Liebeherra).

Oczywiście nie jest wykluczone, że dzieło mogło powstać przed przystąpieniem Liebeherra do stowarzyszenia i nie miało być przedmiotem dyskusji na forum Collectores Historiae et Juris Patrii. Za tym przemawia fakt, iż Liebeherr jeszcze przed 1742 rokiem utrzymywał kontakt z wymienionymi wyżej osobami, a nawet miał pewien wkład w prace nad wydanym w 1730 roku przez Augustina Balthasara dziełem o nazwie notabene Apparatus Diplomatico-Historici ${ }^{29}$. Jednak którąkolwiek z hipotez uznamy za prawdziwą, należy stwierdzić, iż greifswaldzkie stowarzyszenie było zaangażowane w powstanie dzieła bądź przez zlecenie jego napisania w ramach swoich działań statutowych, bądź poprzez udostępnianie kolekcji pieczęci swoich członków. Tutaj nasuwa się potrzeba pogłębionych badań zarówno nad działalnością stowarzyszenia Collectores Historiae et Juris Patrii, jak i nad naukową aktywnością M.H. Liebeherra, dzięki którym być może uda się wyjaśnić zagadkę powstania poszytu Apparatus Sigillorum.

Następnym zagadnieniem, które należy poruszyć jest pochodzenie pieczęci, których szkice znajdują się na kartach Apparatus Sigillorum. Przy części z nich o pochodzeniu informują zapiski dorsalne. Wyżej przeanalizowane zapiski dotyczyły pieczęci pochodzących z prywatnych kolekcji członków stowarzyszenia Collectores Historiae et Juris Patrii, poza nimi jeszcze w kilku innych przypadkach możemy w ten sposób zdobyć informacje. O tym, że pieczęcie Barth znajdowały się w kolekcji Liebeherra dowiadujemy się z zapisku: „Diese 6 Sigilla sind

${ }^{28}$ Greifswaldisches Wochen-Blatt, 13.

29 Augustin von Balthasar, Apparatus Diplomatico-Historici etc. III te Ausfertigung (...), (Greifswald, 1735), 1. 
bey hr. Bürgermeister Liebeher”. Dla pieczęci Demminu lokalizacja pozostaje nierozpoznana - , ist gebrauchet 1605 in einem Vertrag zwischen das $\operatorname{Br}($ ?) und der Gemeine wegen Korn Verschiff in loco vorhanden”. Pieczęcie Łeby najprawdopodobniej znajdowały się w archiwum miasta lub szczecińskim - „In Archiv. St. 1420". Pieczęcie Polic były przechowywane w miejskim archiwum, treść zapisku: „,ist noch in Original der Politz”. Pieczęcie Stargardu również były w posiadaniu miasta - „Alle diese Sigilla sind in originali in Stargard zu finden”. Znów o kolekcji Liebeherra wspomniano przy odrysach pieczęci Usedom - „Diese Sigilla hat hl. Bürgermeister von Liebeher zu originali”. Miejsce przechowywania pieczęci Wolina również pozostaje niezidentyfikowane - „Diese 4 letzte Sigilla habe aus alte Scarteke[?] de anno 1592 und 1679 gefunden”.

Jak widać Liebeherr korzystał także z archiwów miejskich. Najciekawsze jest jednak to, że w przypadku Barth i Usedom wspomniano o zbiorach własnych Liebeherra. Taki zwrot nasuwa od razu spostrzeżenie, że pozostałe sigille, nieposiadająca tego rodzaju dopisków, nie znajdowała się w kolekcji szczecińskiego burmistrza. Również w literaturze dotyczącej zbiorów Liebeherra nie wspomina się słowem o takowej kolekcji, w przeciwieństwie do zbioru monet, które doczekały się nawet własnego opracowania ${ }^{30}$. Oczywiście nie oznacza to, że Liebeherr nie mógł posiadać pieczęci w swojej kolekcji.

Skąd więc pochodziła przeważająca część pieczęci przedstawiona w Apparatus Sigillorum? Tutaj pozostaje oprzeć się na enigmatycznym zapisie z okładki poszytu o treści: Alles diese Sigilla in hoc Apparatus sind meinstenteils in naa(znak kontrakcji) in Stettin auch in Locis vorhanden ${ }^{31}$. Czym są owe miejsca opisane niecodziennym skrótem - tego nie wiadomo. Być może chodzi tu o archiwum szczecińskie, do którego Liebeherr z racji swojej funkcji miał dostęp? Niestety ta kwestia również musi pozostać w sferze spekulacji.

\section{Podsumowanie}

Pomimo skromnej ilości informacji na temat twórcy i okoliczności powstania dzieła zawartych na kartach Apparatus Sigillorum, udało się wysunąć kilka hipotez. Po pierwsze, już przy pierwszym oglądzie dzieła nasuwa się przypuszczenie, że pracowało nad nim co najmniej dwóch rysowników. Po drugie, dzieło było

${ }^{30}$ Johann Gottlieb Lehmann, Verzeichniss einer grosstentheils vollstandigen Sammlung von Pommerischen Munzen..., 2 Th., (Berlin, 1752).

${ }^{31}$ LAG, Rep. 41 Plathe, Nr. I 41. 
z czasem uzupełniane o kolejne miasta $\mathrm{i}$ ich pieczęcie nieujęte $\mathrm{w}$ pierwotnym układzie treści. Po trzecie, można przypuszczać, iż twórcą dzieła był Matthäus Heinrich von Liebeherr, ponieważ to z jego kolekcji dzieło trafiło do rąk Ostena. Po czwarte, pewien związek z powstaniem dzieła miało środowisko pomorskich uczonych, z którymi współpracował Liebeherr. To ich zbiory stanowiły część materiału źródłowego, na którym bazował twórca Apparatus Sigillorum. Po piąte, inspiracją do stworzenia niniejszego dzieła mogła być działalność Liebeherra w ramach stowarzyszenia Collectores Historiae et Juris Patrii, którego członkowie zostali wymienieni w dopiskach na kartach Apparatus Sigillorum. Po szóste, autor dzieła korzystał ze zbiorów archiwów miejskich i tam odnalazł niektóre pieczęcie. Co do reszty odrysów pieczętnych, do których nie dołączono dopisków, możemy jedynie spekulować, że ich wzorce znajdowały się w archiwum szczecińskim, do którego Liebeherr miał dostęp z racji pełnionego urzędu.

W dalszych badaniach nad genezą Apparatus Sigillorum należy uwzględnić działalność greifswaldzkiego środowiska uczonych, a przede wszystkim grupy Collectores Historiae et Juris Patrii. Ciekawych informacji mogłaby również dostarczyć analiza korespondencji Matthäusa Liebeherra. Być może w jej treści uda się odnaleźć wzmianki na temat planów stworzenia dzieła.

\section{Bibliografia}

Źródła niepublikowane

Landesarchiv Greifswald, Rep. 41 Plathe, Nr. I 41.

Źródła publikowane

Balthasar von, Augustin. Apparatus Diplomatico-Historici etc. III te Ausfertigung (...). Greifswald, 1735.

Beckmann, Sabinne. „Drucker, Sammler, Gelehrte. Eine Literatur-und Kulturgeschichte Westpommerns im Spiegel frühneuzeitlicher Gelegenheitkunst”. W: Handbuch des Personalen Gelegenheitsschrifttums in Europäischen Bibliotheken und Archiven, red. Sabinne Beckmann, Stefan Anders, 17-195, Bd. 27. Hildesheim-Zürich-New York: Olms-Weidmann, 2013.

Bernouilli, Johann. Reisen durch Brandemburg, Pommern, Preussen, Curland, Russland und Pohlen in den Jahren 1777 und 1778. Bd. 2. Leipzig, 1779-1780.

Bieniek, Dariusz. „Od pieczęci do herbu”. Gazeta Płotowska, 3 (2016): 3.

Bismarck-Osten von, Ferdinand. „Die Sammlungen zu Schloss Plathe und ihr Begründer Friedrich Wilhelm von der Osten (1721-1786)". Baltischen Studien 62 (1976): $63-72$. 
Bobowski, Bogdan. „Motywy gospodarcze na pieczęciach średniowiecznych i wczesnonowożytnych Goleniowa". W: Najnowsze badania nad numizmatyka i sfragistyka Pomorza Zachodniego: Materiaty z konferencji naukowej 50 lat Działu Numizmatycznego Muzeum Narodowego w Szczecinie 19-20 września 2002 roku, red. Genowefa Horoszko, 185-189. Szczecin: Muzeum Narodowe, 2004.

Bobowski, Kazimierz. „Symbolika pieczęci i herbu miasta Dymina na tle motywów obrazowych pieczęci miejskich Pomorza Zachodniego". Śląski Kwartalnik Historyczny Sobótka 43 (1988), 2: 245-254.

Bobowski, Kazimierz. „Symbolika religijna i kościelna w ikonografii pieczęci miast Pomorza Zachodniego". W: Najnowsze badania nad numizmatyka i sfragistyka Pomorza Zachodniego: Materiały z konferencji naukowej 50 lat Działu Numizmatycznego Muzeum Narodowego w Szczecinie 19-20 września 2002 roku, red. Genowefa Horoszko, 179-184. Szczecin: Muzeum Narodowe, 2004.

Bobowski, Kazimierz. Dawne pieczęcie na Pomorzu Zachodnim: zabytki prawa i kultury z epoki Gryfitów. Szczecin: Glob, 1989.

Böhmer, Wilhelm. „Uebersicht der allgemeine Chroniken und Geschichten Pommerns seit Kantzow". Baltische Studien 3 (1835), 1: 66-171.

Brüggemann, Ludwig Wilhelm. Ausführliche Beschreibung des gegenwärtigen Zustandes des Königl. Preussischen Herzogthums Vor- und Hinter- Pommern. 2 Th., Bd. 1. Stettin, 1784.

Döring, Detlef. „Gelehrte Gesellschaften in Pommern im Zeitalter der Aufklärung”, W: Die Universität Greifswald in der Bildungslandschaft des Ostseeraums, red. Dirk Alvermann, Nils Jörn, Jens E. Olesen, 123-153. Berlin: LIT Verlag, 2007.

Greifswaldisches Wochen-Blatt von allerhand gelehrten und nützlichen Sachen. Greifswald, 1743.

Gumowski, Marian. „Koszalin - jego herb i pieczęcie”. W: Z dziejów Koszalina, red. Henryk Janocha, 95-106. Poznań: Wydawnictwo Poznańskie, 1960.

Gumowski, Marian. „Pieczęcie i herb Słupska”. Zapiski Koszalińskie 4 (1959): 3-14.

Gumowski, Marian. „Pieczęcie i herby niektórych miast pomorskich”. Przegląd Zachodniopomorski 15 (1971), 3: 113-132.

Gut, Paweł. „Typariusze pieczęci miejskich i sądowych z herbami miejskimi w zasobie Archiwum Państwowego w Szczecinie”. Stargardia 4 (2004), 323-335.

Häckermann. „Balthasar, Augustin von”. W: Allgemeine Deutsche Biographie 2, 29-30. Leipzig, 1875.

Häckermann. „Charisius, Johann Ehrenfried”. W: Allgemeine Deutsche Biographie 4, 103. Leipzig, 1876.

Hupp, Otto. Die Wappen und Siegel der Deutschen Städte, Flecken und Dorfen. München, 1898.

Lehmann, Johann Gottlieb. Verzeichniss einer grosstentheils vollstandigen Sammlung von Pommerischen Munzen (...). 2 Th., Berlin, 1752. 
Pyl, Theodor, hrsg. Dr. j. u. Augustin Balthasars [...] Leben und Schriften nach dessen Selbstbiographie und anderen urkundlichen Quellen als Ergänzung zu O. Focks Rügisch-Pommerscher Geschichte. Greifswald, 1875.

Pyl, Theodor. „Schwarz, Albert Georg”. AIllgemeine Deutsche Biographie 33 (1891), 223-226.

Rymar, Edward. „Biblioteka Ostenów - Bismarcków w Płotach. Część 2. Tajemnice rozproszenia". Bibliotekarz Zachodniopomorski 46 (2005), 4: 41-53.

Rymar, Edward. „Biblioteka Ostenów - Bismarcków w Płotach. Część 3. Stare i nowe tropy rozproszenia zbiorów". Bibliotekarz Zachodniopomorski 50 (2009), 3-4: $32-35$.

Rymar, Edward. „Biblioteka Ostenów w Płotach (1)”. Bibliotekarz Zachodniopomorski 45 (2004), 3-4: 36-44.

Senarclens de, Vanessa. „Części rozproszonych księgozbiorów XVIII-wiecznych. Biblioteka zamku Plathe i jej użytkownicy”. W: Unbekannte Schätze. Germanica des 16. Jahrhunderts in der Universitätsbibliothek Łódź / Nieznane skarby. Germanika XVI-wieczne w zbiorach Biblioteki Uniwersytetu Łódzkiego, red. Cora Dietl, Małgorzata Kubisiak, 117-146. Łódź: Wydawnictwo Uniwersytetu Łódzkiego, 2018.

Skiba, Aleksandra. „Kolekcja Matthäusa Heinricha Liebeherra w bibliotece Gimnazjum Akademickiego w Szczecinie”. W: Od Pedagogium Książęcego do Gimnazjum Mariackiego. Z dziejów szkolnictwa pótwyższego w Szczecinie do początków XIX w., red. Agnieszka Borysowska, 159-171. Szczecin: Książnica Pomorska im. Stanisława Staszica, 2018.

Szajko, Urszula. „Liebeherr Mathaus Heinrich von”. W: Encyklopedia Szczecina, red. Tadeusz Białecki, 542. T. 1. Szczecin: Uniwersytet Szczeciński, 1999.

Szukała, Maciej. Powstanie i działalność Towarzystwa Historii i Starożytności Pomorza w Szczecinie w latach 1824-1918. Szczecin: Wydawnictwo Archiwum Państwowego „Dokument” w Szczecinie, 2000.

Zettelkatalog der Bibliothek, Bismarck-osten.com. Dostęp 28.01.2020. http://www.bismarck-osten.com/zettelkatalog.

\begin{abstract}
Abstrakt
Celem artykułu były przedstawienie oraz próba ustalenia autorstwa, czasu i okoliczności powstania nieznanego zbioru odrysów pieczęci miejskich Apparatus Sigillorum Pomeraniae et Rugiae Civitatum. Dzieło zachowało się do naszych czasów w pozostałościach tzw. Biblioteki Ostenów, do której trafiło w 1773 roku. Lakoniczne zapiski na okładce dzieła wskazują na jego pochodzenie z kolekcji Matthäusa Heinricha Liebeherra. Na podstawie analizy estetyki wykonania odrysów możemy przypuszczać, że dzieło posiadało
\end{abstract}


kilku rysowników, być może było uzupełniane przez kolejnego właściciela. Z treści zapisków dorsalnych można wywnioskować, że autor korzystał z pieczęci znajdujących się w zbiorach pomorskich uczonych skupionych w stowarzyszeniu Collectores Historiae et Juris Patrii, prawdopodobnie też sama działalność tegoż stowarzyszenia mogła stanowić inspirację do skatalogowania pieczęci pomorskich miast.

\title{
APPARATUS SigILlORUM - AN UNKNOWN SOURCE FOR MUNICIPAL SPHRAGISTICS OF Western Pomerania: Authorship, time and CirCumstances of its Origin
}

\begin{abstract}
The purpose of the article is presentation of an unknown collection of copies of the municipal seals Apparatus Sigillorum Pomeraniae et Rugiae Civitatum and an attempt to establish authorship, time, and circumstances of its origin. The work survived among the remnants of the so called Ostens Library, where it came in 1773. Brief notes made on its cover suggest that it originates from the collection of Matthäus Heinrich Liebherr. The analysis of the aesthetic of the executed copies allows a supposition that there were several drawers and the work could be completed by the successive owners. The content of the dorsal notes implies that the author used the seals from the collections of Pomeranian scholars belonging to the society Collectores Historiae et Juris Patrii. It is likely that the activity of this society inspired the compilation of the catalogue of the Pomeranian towns' seals.
\end{abstract}

